\title{
LAND OF ORIGINS: A Gemological Expedition to Ethiopia
}

Wim Vertriest, Daniel Girma, Patcharee Wongrawang, Ungkhana Atikarnsakul, and Kevin Schumacher

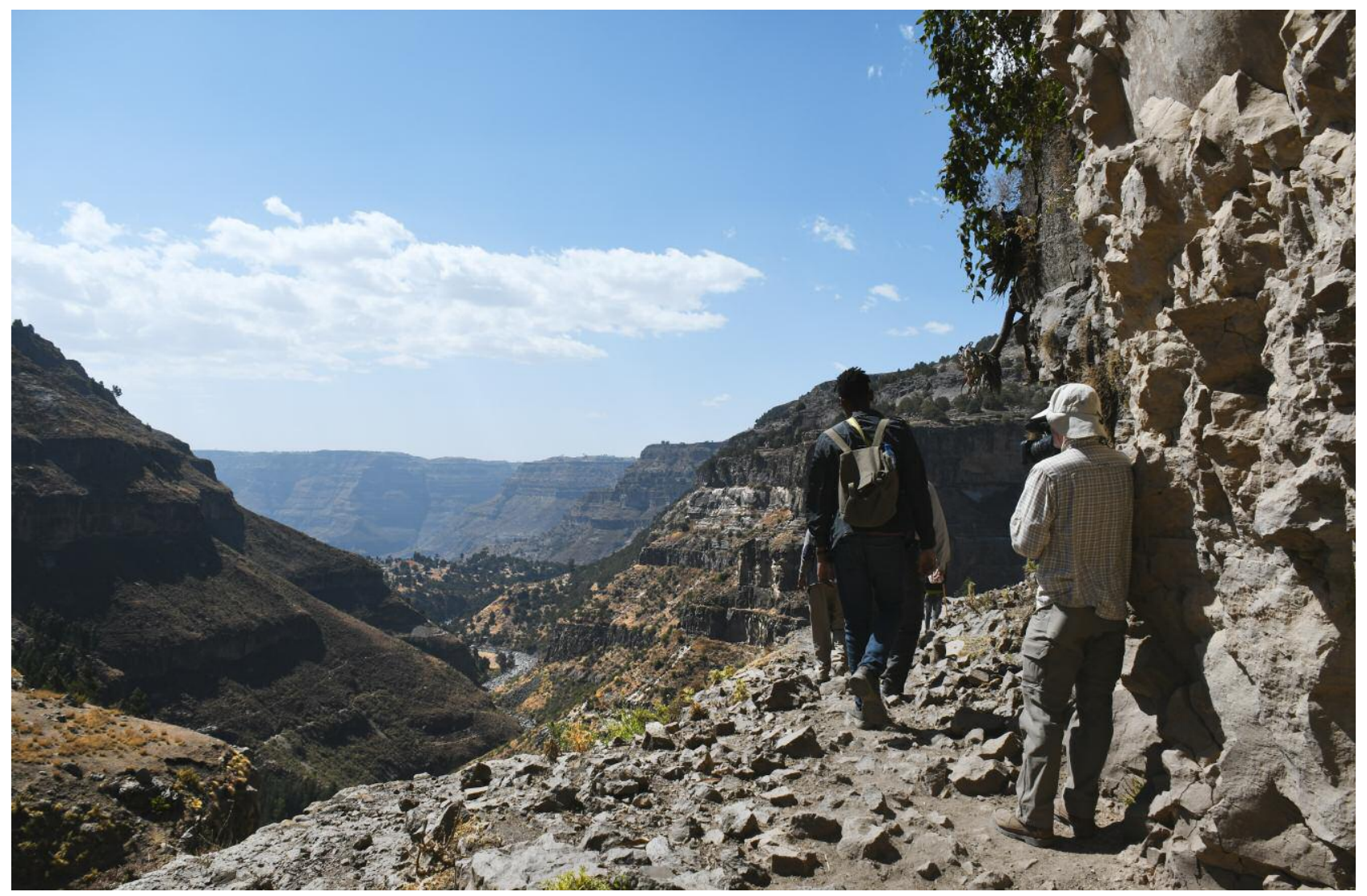

Figure 1. The GIA field expedition team on the way to the Ethiopian opal mines near Wegel Tena. Photo by Wim Vertriest.

$\triangle$ lthough Ethiopia is considered the cradle of mankind and the land of origins, gemstones never played a significant role in its long history and rich culture. Only in the last decade did Ethiopia emerge in the gem trade, with the discovery of large opal deposits near the town of Wegel Tena (Rondeau et al., 2010). When the first high-quality emeralds from Shakiso in southern Ethiopia reached the mar-

See end of article for About the Authors and Acknowledgments.

Gems \& Gemologr, Vol. 55, No. 1, pp. 72-88,

http://dx.doi.org/10.5741/GEMS.55.1.72

(C) 2019 Gemological Institute of America ket in the fall of 2016, GIA's Carlsbad and Bangkok labs conducted a joint preliminary study (Renfro et al., 2017). And in February 2017, GIA received news of a sapphire discovery near Aksum in northern Tigray Province (Vertriest et al., 2017).

With all of this new material reaching the market, GIA collaborated with the Ethiopian Ministry of Mines, Petroleum and Natural Gas in Addis Ababa to set up an expedition to the sapphire, opal, and emerald sources. In March 2018, a team of four GIA gemologists and videographers traveled to Ethiopia to visit its gem sources. The first target was the sapphire deposit in the north, followed by the opal mines in the central highlands. The last area visited 


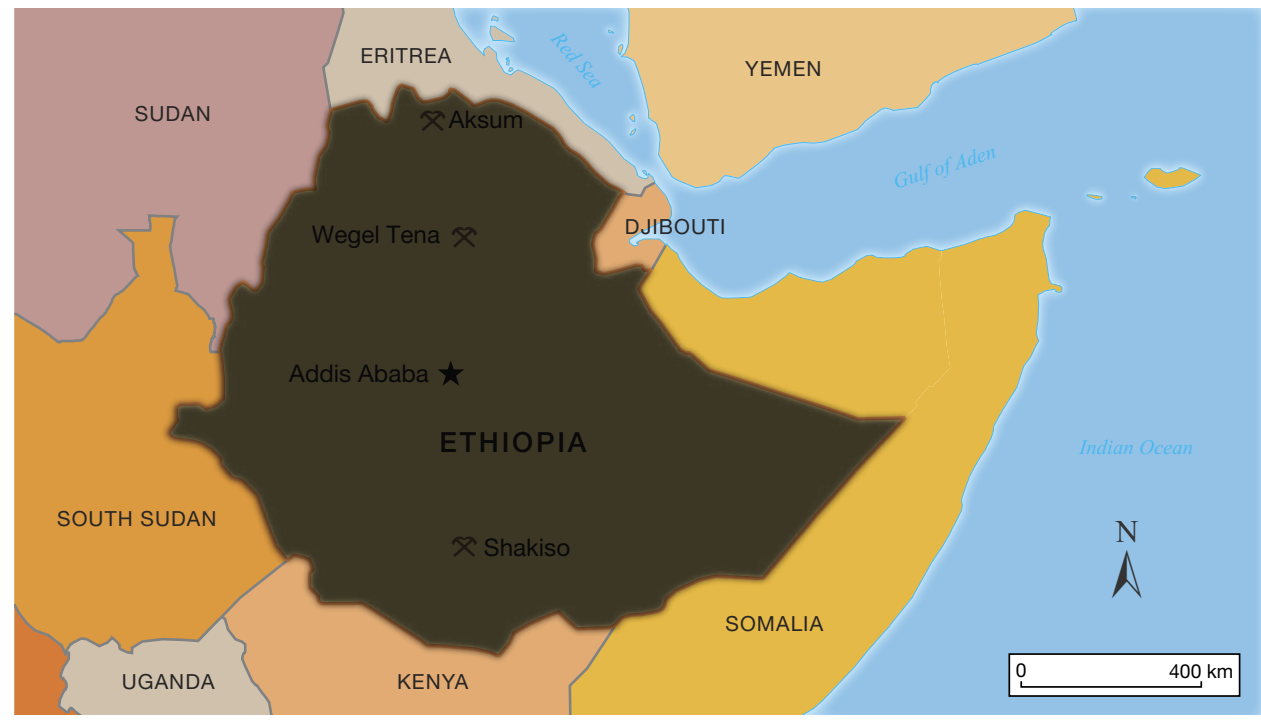

Figure 2. Map of

Ethiopia indicating its main gem sources: sapphire near the town of Aksum, opal in the central highlands surrounding Wegel Tena, and emeralds in the southern jungles near Shakiso.

was near Shakiso to witness the developing emerald mines. During the expedition (figure 1), we documented mining techniques, social impact, material processing, natural challenges, and limitations. We also collected samples at the mines and nearby markets in accordance with GIA's sampling protocols. These samples are now part of GIA's reference collection and used for origin determination, research projects, and treatment experiments.

\section{INTRODUCTION}

Geography and Geology. Ethiopia is a landlocked country in northeast Africa that shares borders with Kenya, South Sudan, Sudan, Eritrea, Diibouti, and Somalia (figure 2). A land of extremes with fertile grasslands, expansive deserts, tranquil lakes, and massive canyons, it hosts one of the sources of the Nile River but also the world's hottest settlement (Dallol). The largest continuous mountain range in Africa, the Simien, contrasts sharply with the barren volcanic wasteland of the Danakil Depression in northeastern Ethiopia. The highest peak of the Simien, Ras Dashen, stands over 4,500 meters $(14,763 \mathrm{ft})$ above sea level, while the lowest parts of the Danakil reach 125 meters (410 ft) below.
The geology of northeast Africa is dominated by two of Africa's biggest geological structures: the African Rift Valley and the Mozambique Belt ${ }^{1}$. The African rift zone is a geologically young feature that is still active and responsible for massive basalt plateaus that make up most of Ethiopia's highland. The zone is also responsible for the low-lying volcanic depression in Afar. The Mozambique Belt is the exposed root zone of an ancient mountain range (550 $\mathrm{Ma}$ ) that once formed the core of the Pangaea continent. It has been subjected to immense stresses, pressures, and temperatures during its long and complex formation.

Ethiopia's population of more than 105 million makes it the second most populous nation in Africa. The two largest ethnic groups are Oromo $(34.4 \%)$ and Amhara (27\%). While the official national language is Amharic, states also designate working languages, such as Oromo and Tigrinya for the states of Oromia and Tigray, respectively. The capital is Addis Ababa, located in the central highlands, with more than 2.7 million inhabitants. Ethiopia is regarded as one of Africa's political centers, and it hosts many important organizations in its capital. The African Union, United Nations Economic Commission for Africa,

\footnotetext{
${ }^{1}$ The Mozambique Belt is a suture zone that developed during the formation of the Gondwana supercontinent. Currently it stretches from central Mozambique up into the Arabian Peninsula. Most of the islands in the Indian Ocean (including Madagascar and Sri Lanka) and parts of southern India and eastern Antarctica are also part of the Mozambique Belt. Today it is exposed at the surface, but once it was covered by more than 10 $\mathrm{km}$ of rocks, which caused it to reach high temperatures and be subjected to incredible pressures. These immense natural forces created many of today's gemstone deposits in East Africa and Asia. It is believed that Mozambique's rubies and most of Madagascar's corundum are related to the Mozambique Belt. In Tanzania, it is linked to the ruby deposits in Longido and Winza, as well as the tanzanite deposits in Merelani. Kenya's most famous gemstone, tsavorite, is also related to this geological feature. On the other side of the Indian Ocean, Sri Lanka's sapphire wealth is attributed to the Mozambique Belt.
} 
Organization of African Unity, and many others are all based in Addis Ababa (Ham and Carillet, 2017).

Culture and Religion. Ethiopia is known as "the land of origins," where many important archeological and paleontological milestones have been uncovered. The earliest human ancestors were discovered in the Afar Depression in northeastern Ethiopia, with Lucy (Australopithecus afarensis) the most famous of them all. She was long considered the first hominid, but more recent discoveries have unearthed even older skeletal remains (Ardipithecus, or Ardi) that may belong to another genus.

Throughout history, Ethiopia has been an important territory in northeastern Africa. Ancient kingdoms were based there, many of which dominated trade around the Horn of Africa and thus between Asia and Europe. Probably the most famous is the Kingdom of Aksum in northern Ethiopia, which is considered to have been the equal of Rome, Persia, and China around 2,000 years ago. Other notable kingdoms were based out of Gondar (post Middle Ages), which is known for the Royal Enclosure, sometimes referred to as "Ethiopia's Camelot."

From about 1850 through World War II, Ethiopia was ruled by a line of emperors that ended with the most influential of all, Haile Selassie. Although Ethiopia has never been colonized, Italy occupied it

Figure 3. Ethiopia's rich cultural history was evident in every locality we visited, such as the Church of Saint George in Lalibela, where this priest guards the relics. Photo by Wim Vertriest.

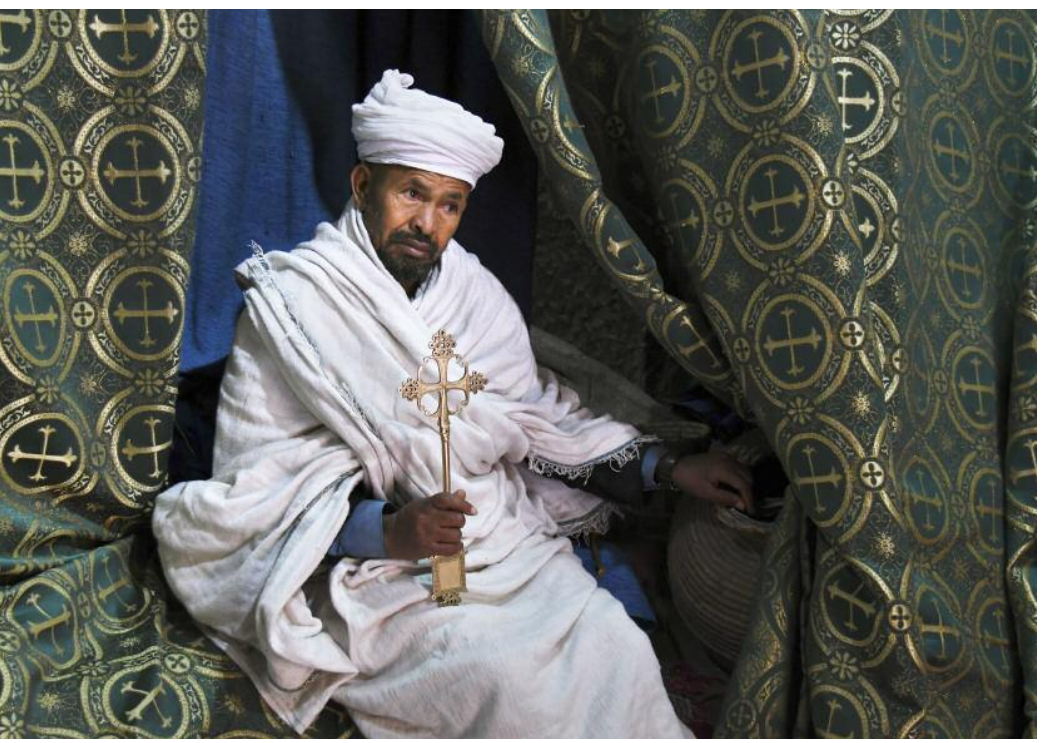

from 1936 to 1941. After World War II, Haile Selassie returned to power and tried to lead the nation into modernity. This led to civil unrest, and in 1974 the Derg communist regime took power. During the regime, hundreds of thousands were deported or died from either hunger or the "Red Terror," a late-1970s cleansing campaign against enemies of the regime. When communist rule ended in 1991, the Federal Democratic Republic of Ethiopia was installed.

The majority of the country is traditionally Ethiopian Orthodox Christian. In 330 CE, King Ezana the Great declared Christianity the state religion, and the faith is deeply rooted in the culture. The epicenter of Ethiopian Orthodox worship is the Church of Our Lady Mary of Zion in Aksum. The original church was built in the fourth century CE and has been destroyed and rebuilt several times. Today, visitors can find the nearby Chapel of the Tablet, which is believed to hold the Ark of the Covenant. Other important locations for the Ethiopian Orthodox faith are the Holy Trinity Cathedral in Addis Ababa, which houses the tomb of emperor Haile Selassie, and the rock-hewn churches in Lalibela (figure 3; see Ham and Carillet, 2017).

Diversity is reflected in every aspect of Ethiopia, from its history to its people and languages to its landscapes.

\section{ETHIOPIAN SAPPHIRE}

Our field trip began at the sapphire deposits in Ethiopia's northern Tigray Province, near the border with Eritrea, which were discovered in the last months of 2016. Rumors of the discovery reached the trade in early 2017, and the first stones were seen in the Asian markets of Chanthaburi (Thailand) and Beruwala (Sri Lanka) in April 2017. Since the initial discovery near Chila, sapphires have been found in many localities throughout Tigray Province.

Background and History. The sapphires are mined in the vicinity of Aksum. This town was the capital of the ancient Aksumite kingdom, which erected intriguing monuments known as stelae. These monoliths, measuring up to 33 meters high, are closely associated with burial tombs of local elite and royalty. Aksum's rich heritage makes it one of Ethiopia's main tourist hubs, so access is convenient and accommodations are readily available.

The sapphires are mined and traded north of the city, in the direction of the Eritrean border. The countries have had a tense relationship since Eritrea regained its independence from Ethiopia in 1991. This 


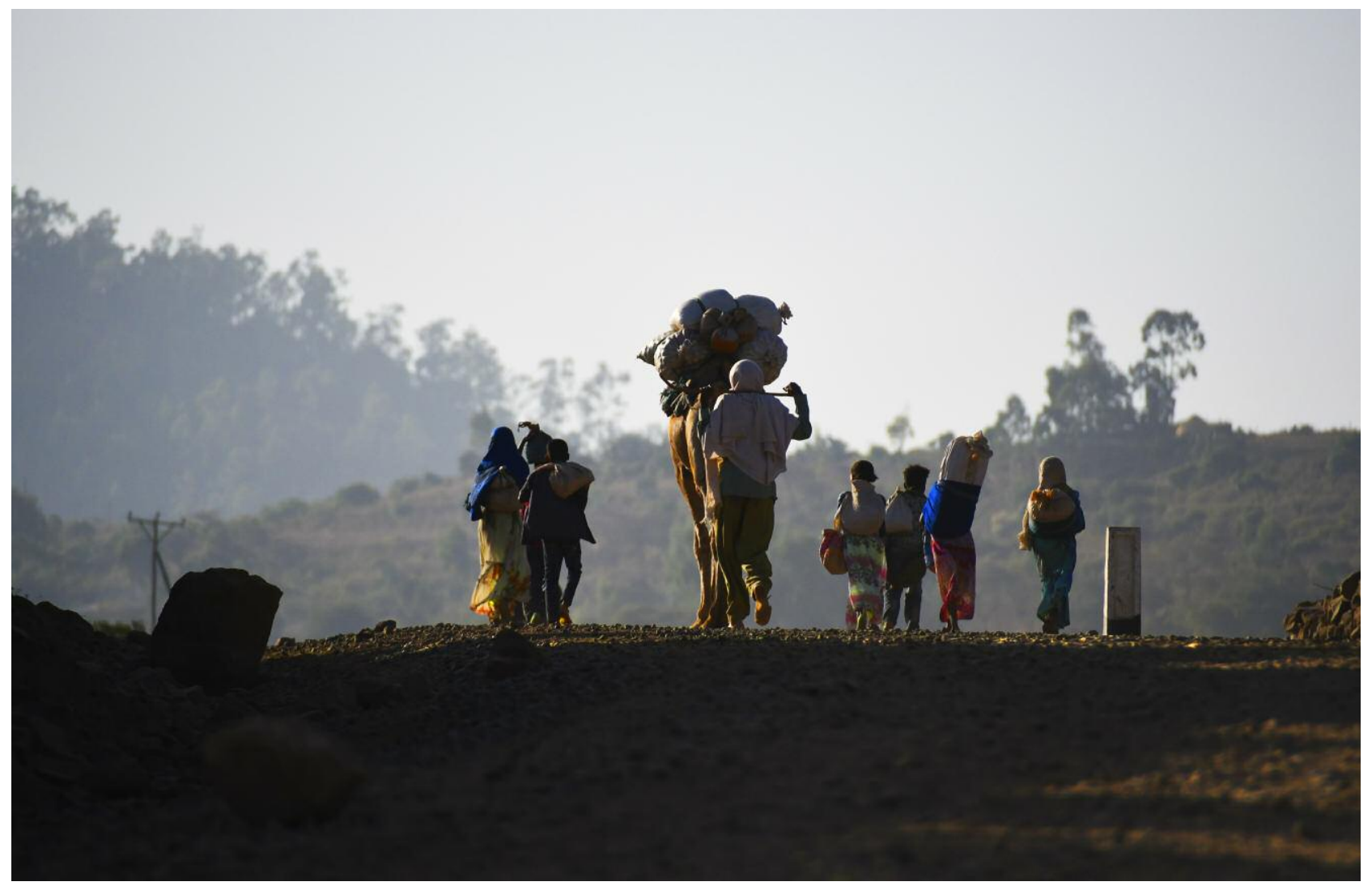

Figure 4. A family with goods packed on their camel travels on the road to the weekly market in Chila. Photo by Wim Vertriest.

has caused many border disputes, often resulting in casualties, although steps toward peaceful resolution have been taken since mid-2018. At the time of our visit, it was nearly impossible for foreigners to travel north of Aksum toward the border, where the sapphire fields are located. Numerous military checkpoints and watch posts are set up along the main roads north from Aksum. The GIA team was only able to visit the off-limits area with special permission from the Ethiopian Ministry of Mines, Petroleum and Natural Gas. Local authorities keep a close eye on every visitor, including Ethiopians from other parts of the country.

The Tigray area is barren and sparsely vegetated. The protected valley where Aksum lies is fertile, but life in the wastelands toward the Eritrean border in the north is much tougher. Dusty, rocky roads wind through the badlands made up of granitic boulders, and only the occasional tree serves as a recognizable landmark. Since the area is remote and road access is limited, most transport is with beasts of burden such as camels and donkeys (figure 4). Despite the harsh and arid climate, people depend heavily on agriculture and their herds of animals. Rainfall is scarce but intensely concentrated, which creates violent periodic rivers. These high-energy water flows move boulders, rocks, and soil with enough power to wash away an entire fertile soil layer in one storm.

Most people know this area as the region most affected during the great famine in the early 1980s. A perfect storm of extreme drought, raging civil war, and failed government policies amplified the devastation. Large international relief efforts were set up, most famously the 1985 Live Aid concert in London. Longerterm plans supported by the United Nations Food and Agricultural Organization aimed to provide sustainable and robust farming methods to increase local food production. This was done mainly by improving soil conditions through terracing and preserving farmlands.

Trading. The sapphire mines are located near the town of Chila, $25 \mathrm{~km}$ northwest of Aksum. There are around 250 buildings in the town and numerous services for many people and smaller communities in the surrounding desert. During the local market every Saturday, crowds gather in the main street to buy and sell goods ranging from livestock to handicrafts-and, since late 2016, Ethiopian sapphires. 


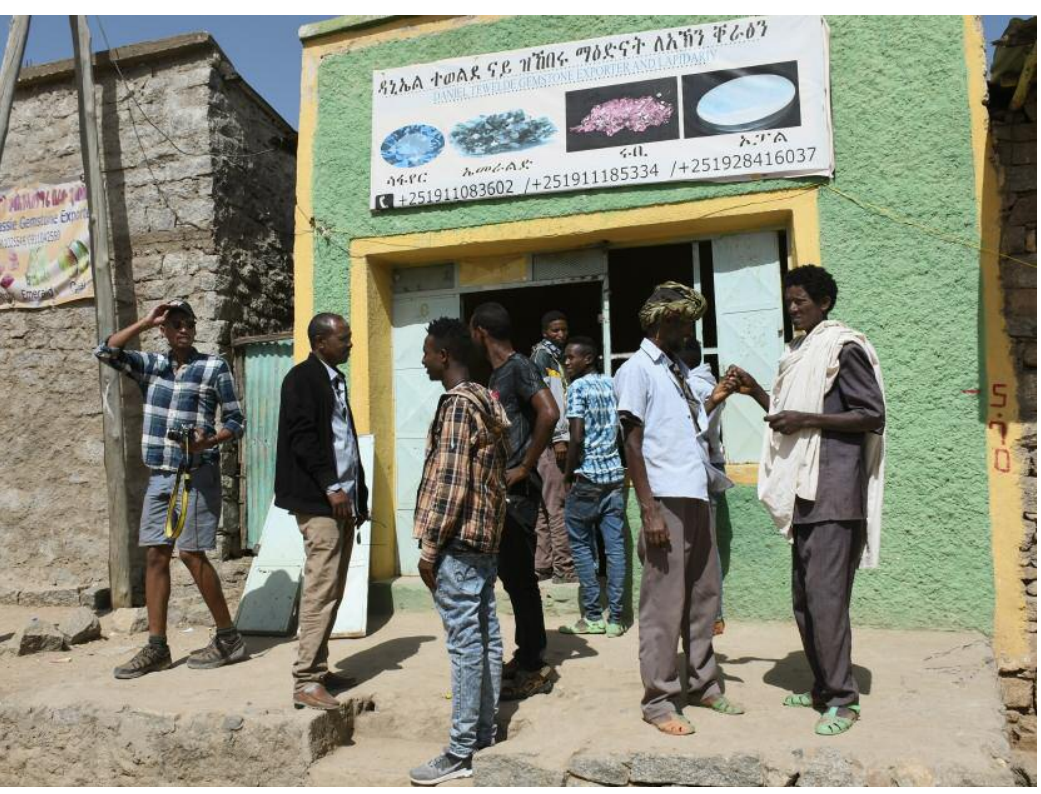

Figure 5. Gem dealers gather in front of their offices during the weekly market in Chila. Photo by Wim Vertriest.

Ethiopian dealers have set up offices in Chila, where they buy gems at the Saturday market (figure 5). The trade there is limited to sapphire and the occasional red garnet. During our visit, more than 15 offices were open in the town. It is illegal for foreigners to go to Chila and the mining areas, let alone buy gemstones near the mines. Local dealers take the goods to Addis Ababa, where foreign buyers can purchase and export the stones. Most of the foreign buyers are Sri Lankans and Thais, who will improve the stones' appearance with heat treatment.

Chila has benefited greatly from the gem trade. During our visit, we saw that many new buildings had been erected. Before the discovery, there was one small bank branch; there are now three banks with full branches in the village. The police station has also been upgraded, and law enforcement actively monitors the presence of sapphire buyers. Several foreign buyers were arrested in 2017 for attempting to purchase in the village.

Geology. We visited a mining site, Godefey, located a few kilometers north of the trading town. More than 500 people were there searching for sapphires. Based on our initial observations, the geological makeup of the area is fairly straightforward. The basement (shown in figure 6) is made up of very resistant rocks that have experienced multiple episodes of metamorphism, with numerous folding and vein-forming phases. When these rocks were exposed at the surface, they weathered down to a relatively flat surface (known to geologists as a peneplain).

Later this flat land was covered in thick basalt flows (see figure 6). These basalt extrusions brought the sapphires to the surface and liberated them slowly while they eroded. The lava flows are still visible in

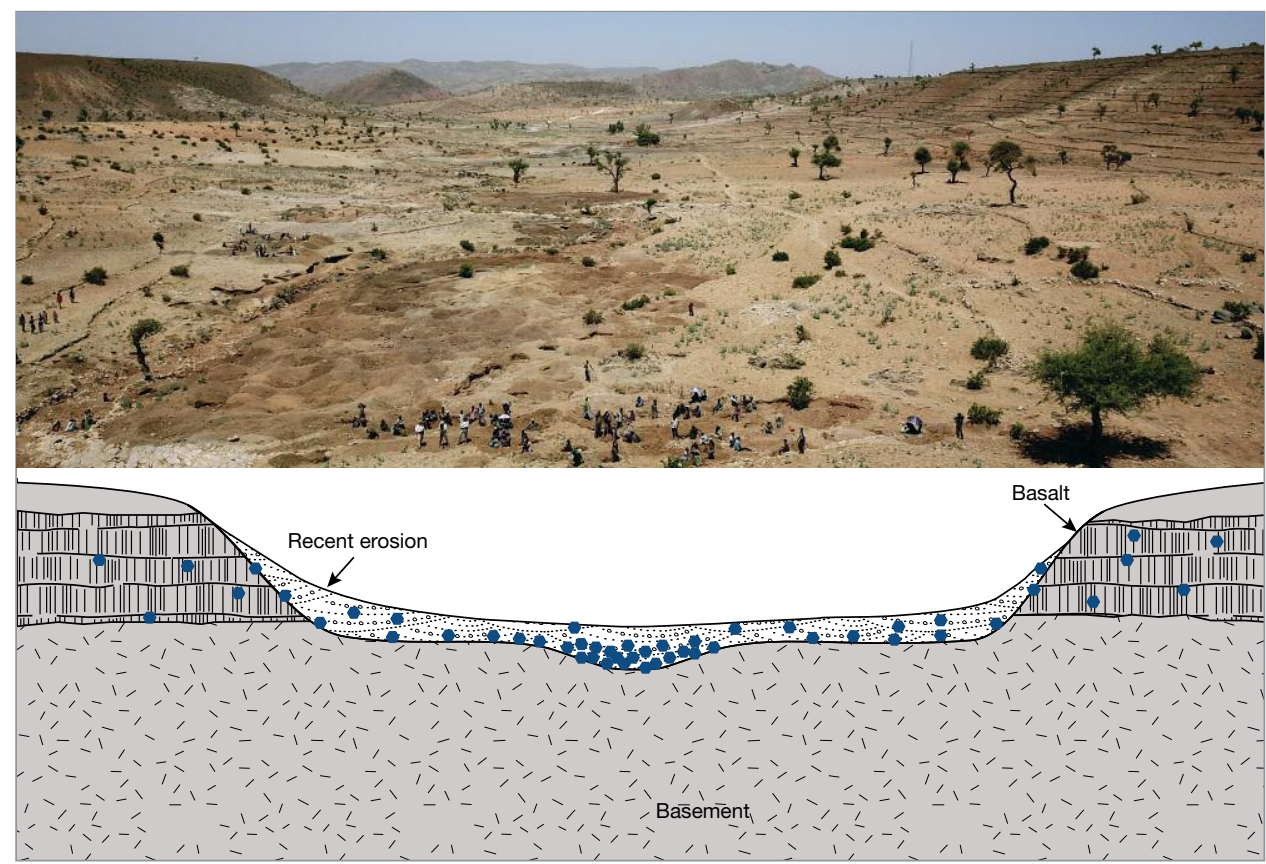

Figure 6. A schematic cross-section of the Godefey mining area (in which the blue hexagons represent sapphire) shows the basalt flows, recent erosion products, and the basement. Photo by Wim Vertriest. 


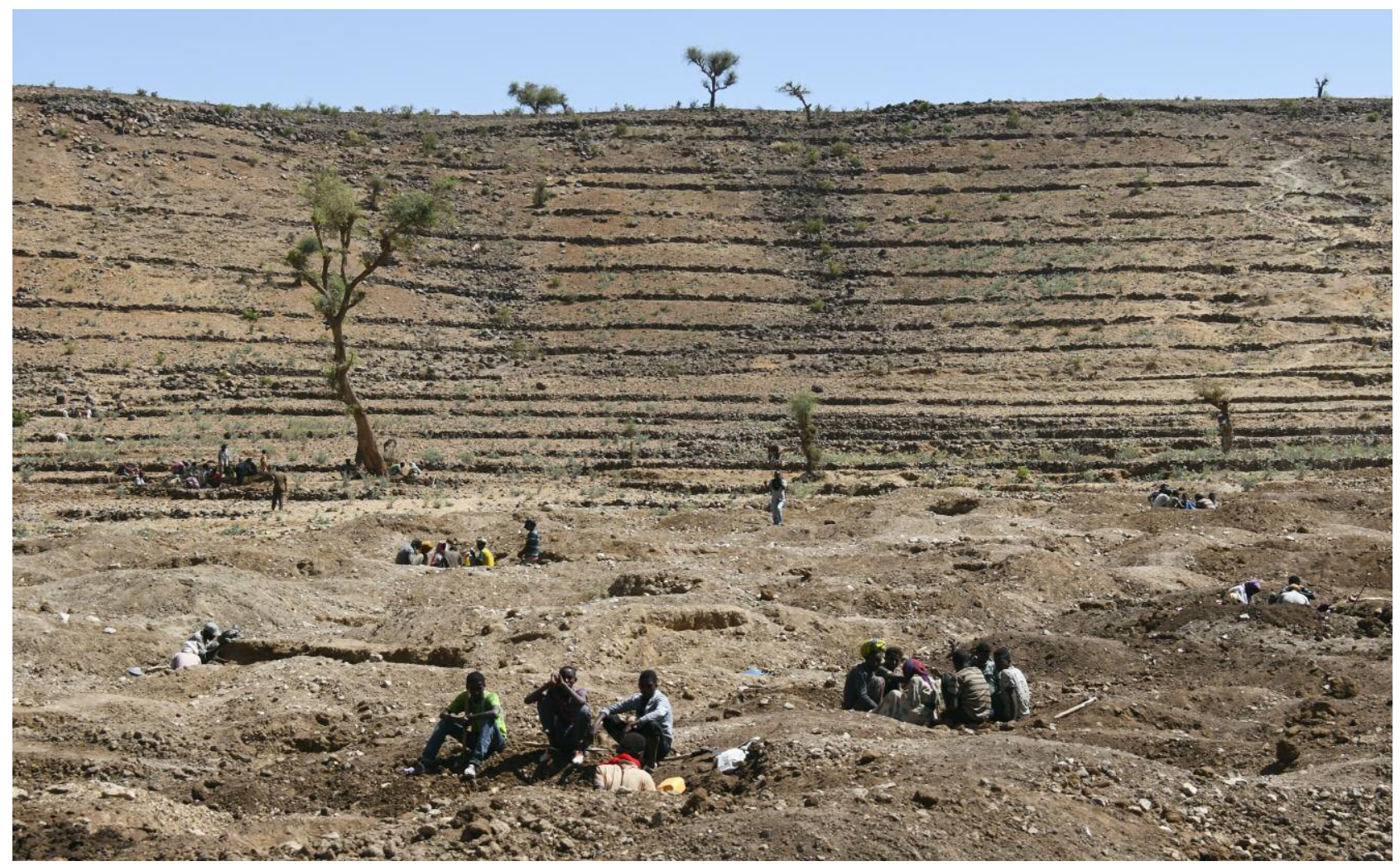

Figure 7. Mining crews at Godefey sit next to their pits. The terraces on the hills are built to optimize agricultural yield. Photo by Wim Vertriest.

the current topography, where all the plateaus are very flat and of uniform height. These plateaus are crosscut by multiple broad valleys, which started as "V" shapes eroding in the basalts. Once they reached the contact with the much harder basement, they started to widen to the broad valleys we see now. During weathering of the basalt, the main minerals such as pyroxene and olivine broke down very rapidly. This means that more-resistant minerals such as corundum, garnet, and zircon accumulated in the debris. These heavy minerals were then transported by water to the center of the valley and became concentrated in placer deposits such as river bends or cavities in the basement.

Mining. Most of the mines are situated in the center of the valley, near the exposed riverbeds. This is where the highest concentrations of minerals should be found. Some miners work higher up on the hillside, and sapphires have reportedly been found on top of the basalt plateaus. This would indicate that the entire basalt plateau is sapphire bearing. In most places, the hills are terraced in an effort to limit soil erosion from heavy rainfall (figure 7). To protect their food sources, landowners do not allow mining on land set aside for crops.
All mining activity is artisanal, with minimal equipment. Crews of five to twelve people, including many entire families, operate together (figure 8). Using simple tools such as shovels and picks, the miners dig

Figure 8. A family crew works together to extract sapphires from a pit. Photo by Wim Vertriest.

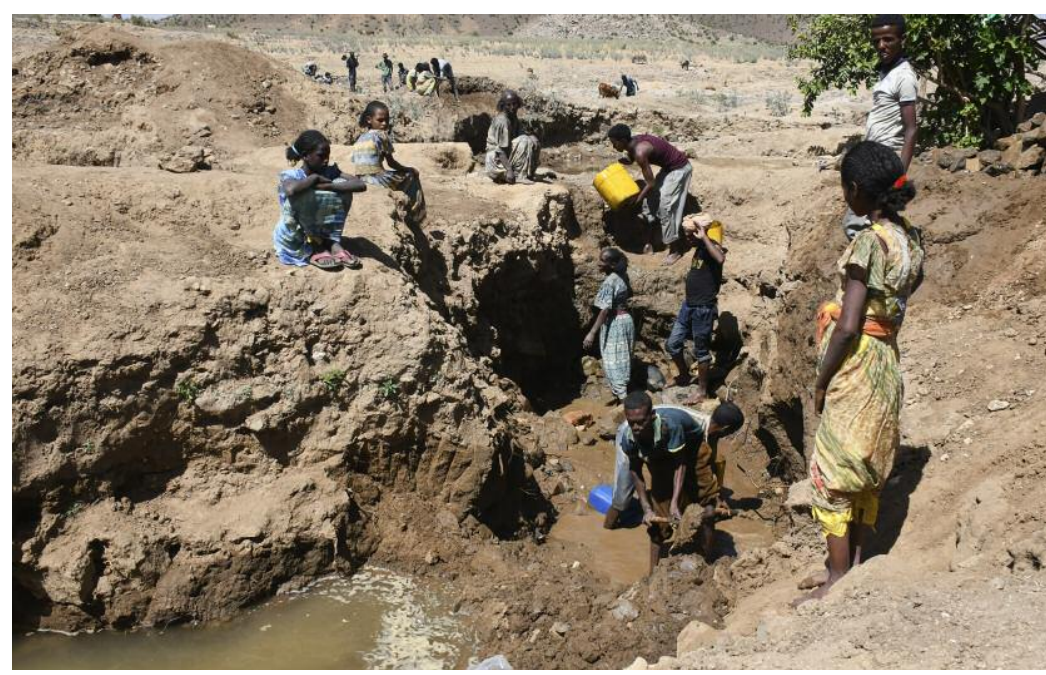




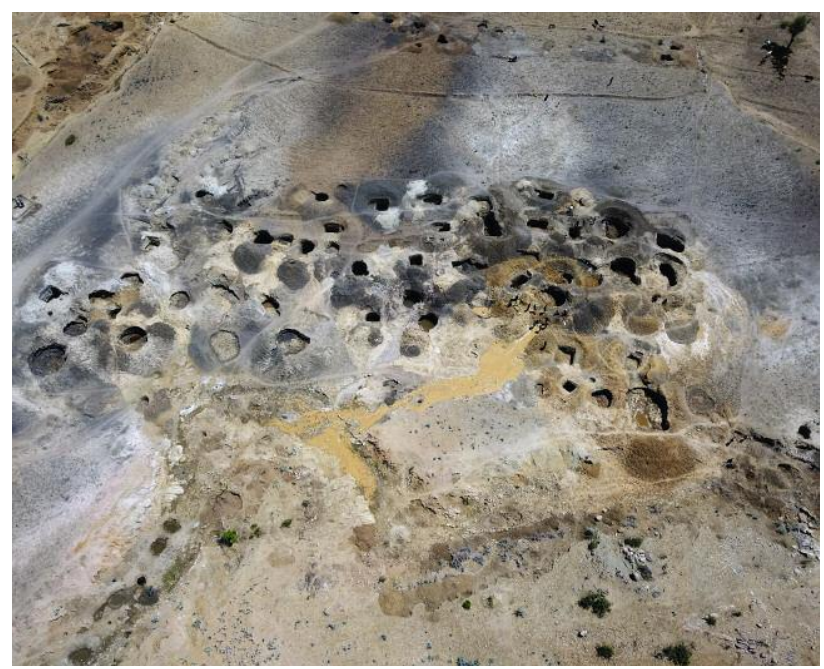

Figure 9. Aerial view of mining pits in the Godefey area. Photo by Wim Vertriest.

pits until they reach a gravelly layer. This layer is typically deposited straight on the hard rock basement, at depths of one to three meters. Gem-bearing gravel is loosened and thrown to the surface or passed along in buckets. Miners dump the gravel onto the ground next to the pit, where it is searched by hand for sapphires.

This is often a completely dry process, with no washing or concentration involved due to the lack of water. Only in rare cases is the water table cut and the pit flooded. We observed one crew using a diesel pump to remove the excess water, while the rest did this manually with buckets or an ingenious wooden pedal pump. The water is not stockpiled or used for washing purposes; at most it is poured over the gravel to clear some of the finer sand.

Overall the mining techniques are very primitive, and we believe this leads to a much lower yield.
Only large stones (>1 ct) with obvious colors are picked out. Smaller goods, stones covered in dust or mud, and other potentially valuable specimens are all discarded. Yet it would be difficult to improve the situation under the circumstances. The area's remoteness makes it challenging to bring in heavier equipment, and fuel supply is irregular. Water is even more scarce (see figure 9), and there are no nearby bodies of water where communal washing efforts could be set up. The river is only seasonal, created by flash floods, making it hard to capture the water. The current mining is very strenuous and employs many hands, which means that many locals receive some portion of their income from sapphire mining.

\section{PROPERTIES OF ETHIOPIAN SAPPHIRE}

Visual Characteristics. The gemstones found in northern Ethiopia are mainly blue sapphires. Since they are related to alkali basalt extrusions, they show characteristics very similar to sapphires from other magmatic deposits, such as those in Australia, Thailand, or Nigeria. These deposits are called BGY sapphire deposits because they predominantly yield blue, green, and yellow colors (figure 10). They also routinely produce black sapphires, whose dark bodycolor is caused by their high content of iron-rich inclusions. The majority of Ethiopian sapphires are blue, with a few pure (dark) yellows. Often one finds stones containing different colors as subtle color zones, or even as full parti-colors. Black bands may occur, caused by high concentrations of particles in certain zones. The locals describe these as "zebra sapphires." Fully black sapphires and star sapphires have not been observed.

Figure 10. Left: High-quality blue sapphires from northern Ethiopia. Right: A lower-grade parcel of sapphires with fancy-color specimens mixed in. Photos by Wim Vertriest.
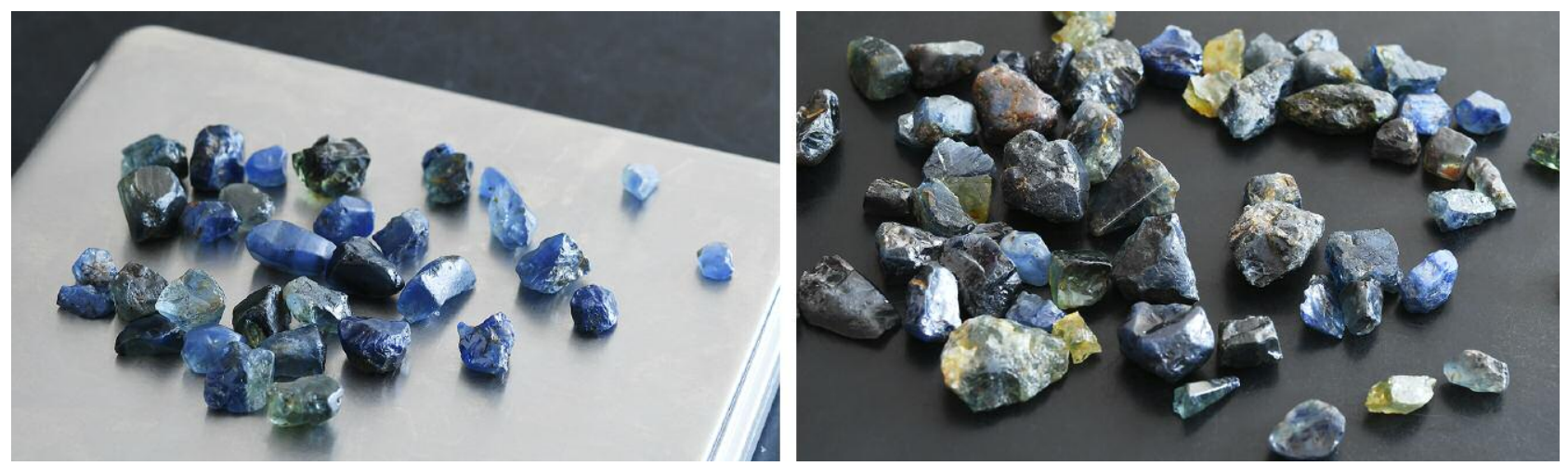

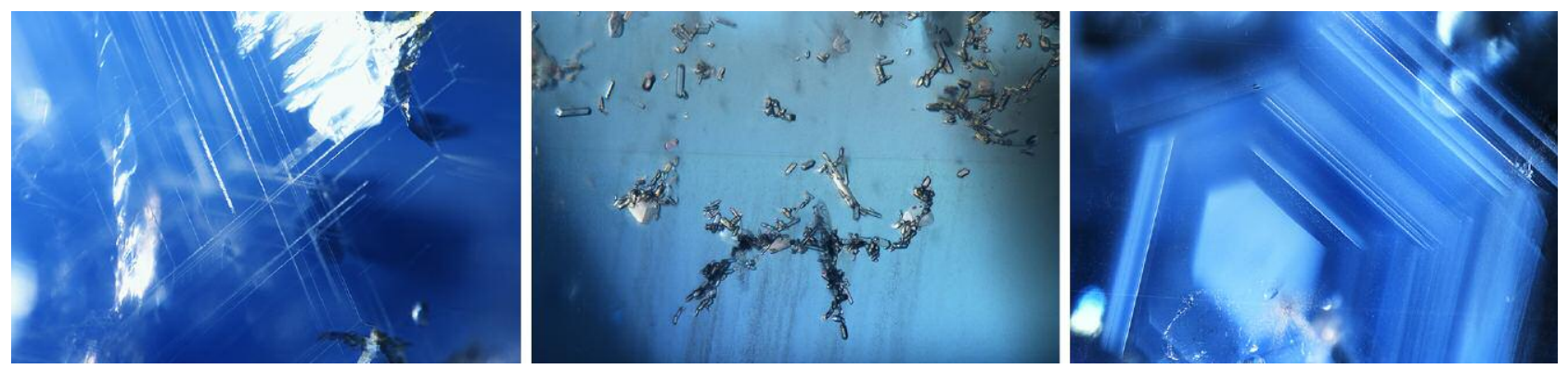

Figure 11. Left: Lamellar twinning with intersecting growth tubules under fiber-optic illumination; field of view $3.6 \mathrm{~mm}$. Center: Cluster of zircon; field of view $1.8 \mathrm{~mm}$. Right: Angular band of minute particles under fiber-optic illumination; field of view $3.6 \mathrm{~mm}$. Photomicrographs by Charuwan Khowpong.

The color of the blue sapphires ranges from dark greenish blue to a pleasing light blue. Dichroism is often very strong. In the milkier stones with fine rutile clouds, a yellowish cast is often observed when put to the torch. This is due to the Tyndall effect, the scattering of light when it interacts with the small particles. The sapphires are very large, with rough stones ranging from $1 \mathrm{ct}$ to more than $100 \mathrm{ct}$.

Inclusions. Ethiopian sapphires are characterized by a variety of inclusions similar to those observed in sapphires from other basalt-related sources. Most notable are twinning planes (figure 11, left), in which two nonparallel sets are common. These planes show growth tubules that intersect. It is often easier to spot the tubules than the twinning planes unless the stone is being evaluated between crossed polarizers. These tubules are sometimes associated with small fingerprints.

Crystal inclusions vary: opaque ferrocolumbite crystals, large feldspar and monazite crystals, and small but well-formed zircon crystals. The zircon inclusions are often found in clusters (figure 11, center). Larger solitary inclusions often form comet tails (trails of fine particles/dislocations). One sample showed interesting inclusions of corundum crystals within the sapphire.

By far the most common inclusions are particles, and two distinct varieties are found in Ethiopian sapphires. The first is a classic rutile particle, seen as clouds, needles, or streamers or in hexagonal bands. These bands (figure 11, right) often contain a second type of particle as well. These are more ironrich, and their composition ranges between ilmenite and hematite. Their appearance is distinct, and they are often more concentrated. The iron-rich particles have a golden brown reflection compared to the silvery white appearance of the classic titanium-rich silk.
Spectroscopy. Ultraviolet/visible/near-infrared (UVVis-NIR) spectra show a typical pattern for basalt-related blue sapphire: bands due to $\mathrm{Fe}^{3+}$ and $\mathrm{Fe}^{2+}-\mathrm{Ti}^{4+}$ pairs that create the blue color. These chromophores are very strongly dependent on orientation, explaining the obvious dichroism in these stones. The broad band outside the visible range at $880 \mathrm{~nm}$ is typical for basalt-related blue sapphires.

Trace-Element Chemistry. We analyzed 50 sapphires from Tigray using laser ablation-inductively coupled plasma-mass spectrometry (LA-ICP-MS) to determine their trace-element concentrations. We analyzed three to fifteen points on each sample, often in different zones of the stone. This gave us a total of 718 data points, of which 194 were in blue zones without visible particles, 193 in zones with visible particles, and 331 in zones with very distinct particles, such as dense milky clouds or iron-rich silk.

Table 1 provides some insight into the chemical analyses of these samples. Beryllium was detected in several stones, in both clean and visibly included areas. Higher concentrations were found in the heavily included zones. Other elements such as niobium, tantalum, tungsten, and zircon followed similar trends. Titanium was clearly enriched in the most included zones but was also present at lower quantities in non-included zones. All of these elements probably exist in particles of various sizes that might be too small to observe with a conventional microscope. Only one heavily included sample showed the presence of chromium, probably due to particles as well. Iron concentrations were always very high, with an absolute minimum of $750 \mathrm{ppma}$ and a maximum near 5000 ppma.

\section{ETHIOPIAN OPAL}

Background and History. Opal has been recovered from Ethiopia's Wollo region since the 1990s, al- 
though production volume and quality were initially very low (Koivula and Fritsch, 1994). In 2008, production increased when deposits of white precious opal were found near Wegel Tena (Rondeau et al., 2009). In 2013, a deposit of black opals was found 30 $\mathrm{km}$ away (Kiefert et al., 2014). During the past decade, Ethiopian opals have reached the market in large quantities. Most of the material is processed in Jaipur and serves the Indian market.

The opal deposits occur in a remote area of Ethiopia, between the towns of Dessie and Lalibela. The terrain consists of high plateaus (approximately
3,000 meters) crosscut by wide, steep valleys about 1,000 meters deep (figure 12). The fertile highlands are well suited for agriculture. Teff, the native grain and the staple of the Ethiopian diet, is grown here. The yearly precipitation is only $20 \%$ less than that of Seattle, Washington, but $95 \%$ of this rain falls in the span of a few weeks. These huge volumes of water move across the valleys with enormous power, cutting them deeper every year. When the riverbed is completely dry, the base of a valley is strewn with house-sized boulders that are transported by the seasonal torrents.

TABLE 1. Concentrations (in ppma) of selected trace elements in Ethiopian sapphires (718 analyses total).

\begin{tabular}{|c|c|c|c|c|c|c|c|c|c|c|c|c|c|}
\hline & ${ }^{9} \mathrm{Be}$ & ${ }^{24} \mathrm{Mg}$ & ${ }^{47} \mathrm{Ti}$ & ${ }^{51} \mathrm{~V}$ & ${ }^{53} \mathrm{Cr}$ & ${ }^{57} \mathrm{Fe}$ & ${ }^{69} \mathrm{Ga}$ & ${ }^{90} \mathrm{Zr}$ & ${ }^{93} \mathrm{Nb}$ & ${ }^{178} \mathrm{Hf}$ & ${ }^{181} \mathrm{Ta}$ & ${ }^{182} \mathrm{~W}$ & ${ }^{232} \mathrm{Th}$ \\
\hline \multicolumn{14}{|l|}{$\begin{array}{l}\text { Blue zones }^{\text {a }} \\
\text { (194 analyses) }\end{array}$} \\
\hline $\begin{array}{l}\% \text { of samples } \\
\text { above detection } \\
\text { limit }\end{array}$ & $17 \%$ & $100 \%$ & $100 \%$ & $100 \%$ & $0 \%$ & $100 \%$ & $100 \%$ & $11 \%$ & $26 \%$ & $8 \%$ & $28 \%$ & $7 \%$ & $13 \%$ \\
\hline Average & 4 & 5 & 57 & 4 & - & 1291 & 47 & 0.0109 & 1.5826 & 0.0018 & 2.1317 & 0.1013 & 0.0059 \\
\hline Max & 17 & 24 & 852 & 12 & $b d l^{d}$ & 3797 & 119 & 0.0492 & 13.8718 & 0.0048 & 14.9883 & 0.2884 & 0.0316 \\
\hline Min & 1 & 1 & 4 & 0 & bdl & 748 & 28 & 0.0009 & 0.0014 & 0.0003 & 0.0007 & 0.0017 & 0.0001 \\
\hline $\begin{array}{l}\text { Standard } \\
\text { deviation }\end{array}$ & 5 & 4 & 137 & 3 & - & 485 & 17 & 0.0107 & 2.9783 & 0.0013 & 4.2765 & 0.1237 & 0.0087 \\
\hline \multicolumn{14}{|l|}{$\begin{array}{l}\text { Particles }^{\mathbf{b}} \\
\text { (193 analyses) }\end{array}$} \\
\hline $\begin{array}{l}\% \text { of samples } \\
\text { above detection } \\
\text { limit }\end{array}$ & $15 \%$ & $99 \%$ & $100 \%$ & $100 \%$ & $0 \%$ & $100 \%$ & $100 \%$ & $10 \%$ & $28 \%$ & $5 \%$ & $41 \%$ & $3 \%$ & $13 \%$ \\
\hline Average & 4 & 6 & 47 & 6 & - & 1326 & 41 & 0.0464 & 3.9063 & 0.0158 & 1.2840 & 0.0529 & 0.0468 \\
\hline Max & 70 & 20 & 371 & 15 & bdl & 3907 & 80 & 0.6371 & 161.984 & 0.1200 & 67.8419 & 0.1852 & 1.0018 \\
\hline Min & 1 & 0 & 12 & 0 & bdl & 752 & 26 & 0.0015 & 0.0014 & 0.0006 & 0.0004 & 0.0021 & 0.0000 \\
\hline $\begin{array}{l}\text { Standard } \\
\text { deviation }\end{array}$ & 13 & 5 & 46 & 4 & - & 637 & 11 & 0.1423 & 22.1774 & 0.0354 & 7.8879 & 0.0733 & 0.1945 \\
\hline \multicolumn{14}{|l|}{$\begin{array}{l}\text { Heavy particles } \\
\text { (331 analyses) }\end{array}$} \\
\hline $\begin{array}{l}\% \text { of samples } \\
\text { above detection } \\
\text { limit }\end{array}$ & $12 \%$ & $100 \%$ & $100 \%$ & $100 \%$ & $2 \%$ & $100 \%$ & $100 \%$ & $14 \%$ & $30 \%$ & $7 \%$ & $47 \%$ & $10 \%$ & $11 \%$ \\
\hline Average & 13 & 6 & 125 & 7 & 2 & 1264 & 43 & 0.1166 & 5.1534 & 0.0483 & 2.0515 & 0.0576 & 0.1125 \\
\hline Max & 91 & 27 & 1486 & 17 & 4 & 4966 & 114 & 1.0686 & 73.5294 & 0.2513 & 42.4857 & 0.3039 & 0.4605 \\
\hline Min & 0 & 1 & 16 & 0 & 1 & 803 & 27 & 0.0007 & 0.0014 & 0.0007 & 0.0004 & 0.0016 & 0.0003 \\
\hline $\begin{array}{l}\text { Standard } \\
\text { deviation }\end{array}$ & 22 & 4 & 211 & 4 & 1 & 597 & 16 & 0.2424 & 13.0648 & 0.0708 & 6.2452 & 0.0813 & 0.1435 \\
\hline Detection limit & 0.19 & 0.18 & 0.59 & 0.04 & 0.45 & 0.77 & 0.02 & 0.0007 & 0.0009 & 0.0001 & 0.0001 & 0.0001 & 0.0013 \\
\hline $\begin{array}{l}{ }^{a} \text { Blue zones: blue b } \\
{ }^{b} \text { Particles: blue bod } \\
\text { "Heavy particles: bl } \\
{ }^{d} \text { bdl: below detecti }\end{array}$ & $\begin{array}{l}\text { lycolor } \\
\text { olor wi } \\
\text { or gre } \\
\text { limit }\end{array}$ & $\begin{array}{l}\text { without } \\
\text { th fine pa } \\
\text { nish boa }\end{array}$ & $\begin{array}{l}\text { isible pa } \\
\text { articles } \\
\text { yycolor w }\end{array}$ & iticles & rge a & irregu & partic & ually & a higher 1 & mponent & & & \\
\hline
\end{tabular}




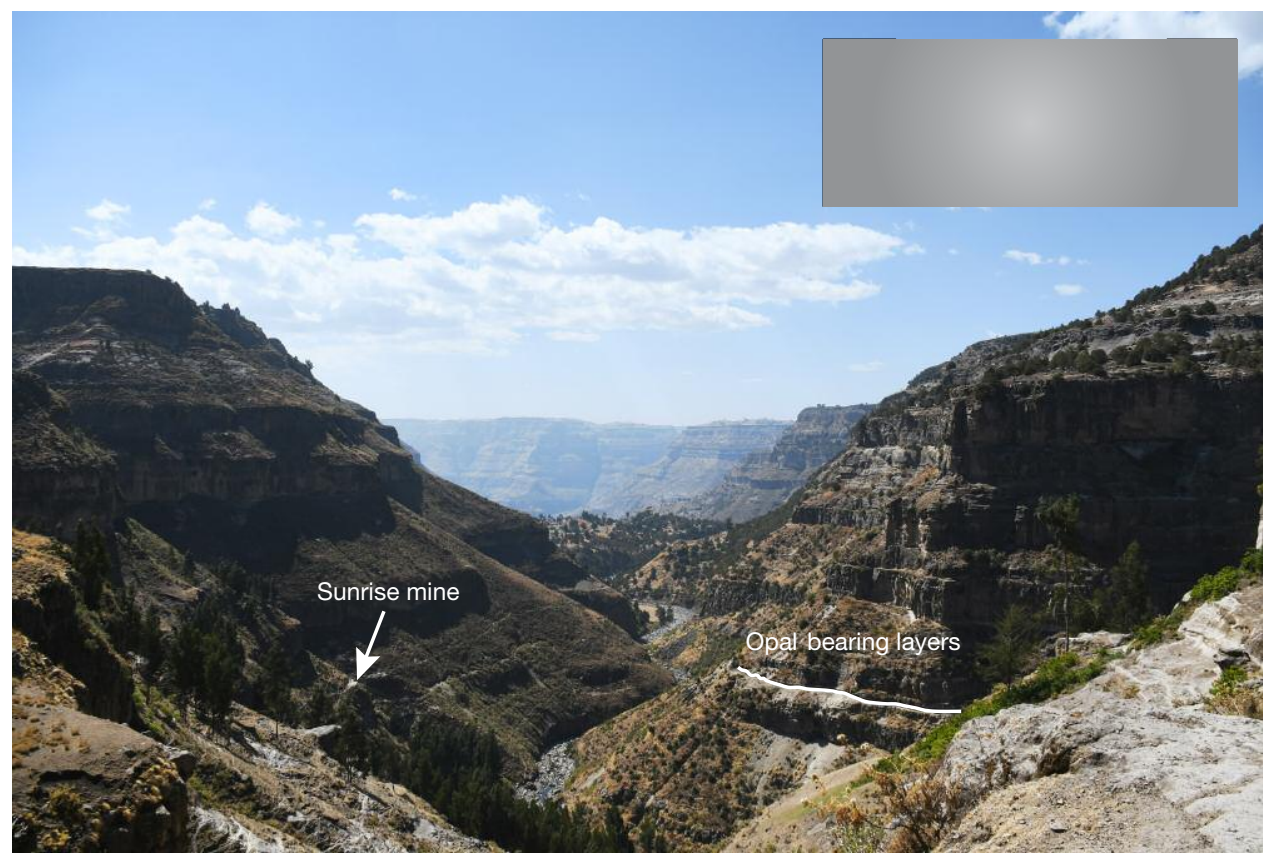

Figure 12. Cross-section of a valley where Ethiopian opal is mined. The opal-bearing layers indicated on the photo are marked in brown in the inset. The arrow points to the Sunrise mine. Photo by Wim Vertriest.

This topography makes travel very difficult since the canyons take several hours to cross even with allterrain vehicles. The direct distance between Lalibela and Wegel Tena is around $50 \mathrm{~km}$. Because we had to cross the Bashilo canyon, the trip took nearly seven hours. Yet the views were magnificent as we wound down the canyon on dusty roads. Indigenous wildlife such as ibex, birds of prey, and gelada monkeys inhabit the cliffs and valleys, often foraging in the fields near the plateau edge. This perilous journey requires a very skilled driver and a vehicle in excellent condition.

Geology. The geology of the opal mining areas is dominated by stacked horizontal layers of volcanic origin. The sequence is over 3,000 meters thick and consists of alternating layers of varying composition ranging from basalt to rhyolite. Some of the individual layers are more than 100 meters thick. These were deposited during extreme volcanic events related to opening of the East African rift zone about 30 million years ago. Opal mineralization is restricted to a single thin layer with a rhyolite (silicasaturated) composition. No other opal-bearing layers have been found to date.

Traditionally, Ethiopian opal has been considered a volcanic opal, similar to Mexican opal. Australian opal is believed to have a sedimentary origin. However, recent studies suggest that Ethiopian opal has a strong sedimentary component. According to Rondeau et al. (2012), these opals might have formed in soil conditions (pedogenic). This is based on micro- scopic observations of plant fossils in the opals, as well as several features that are typical for soils: desiccation cracks, presence of clay minerals, and grain sorting.

It is assumed that Ethiopian opal formed during a calmer period, without new volcanic deposits, where soils could develop and support plant life. During this period, volcanic glass would disintegrate and dissolve in fluids, and feldspar would be altered to clay. The silica-enriched fluids deposited the opal in voids throughout the soil horizon. They often preserved the soil textures, which we see today as inclusions or opal textures (Rondeau et al., 2012).

Mining. Because the opal is found in a single thin horizontal layer, all of the mines are located at the same level in the valleys. The opal-bearing layers are about $350 \mathrm{~m}$ below the top plateau. The only way to reach it is by trails. No animals other than goats and sheep can traverse the steep paths. This means that the miners must carry down all supplies and equipment, and all opal-bearing rocks must be carried up.

Crews of 10 to 20 miners work together to extract the opal. First, they dig a narrow tunnel into the horizontal layer and remove the host rock and opal with simple hand tools (figure 13). The tunnels can reach lengths of more than 70 meters and are sometimes only 40 centimeters wide. It is relatively easy to carve through the rocks since they are fairly soft and not well solidified. There is no need for explosives in these mines. While the temperatures inside the tunnels are relatively cool, the humidity is high and oxy- 


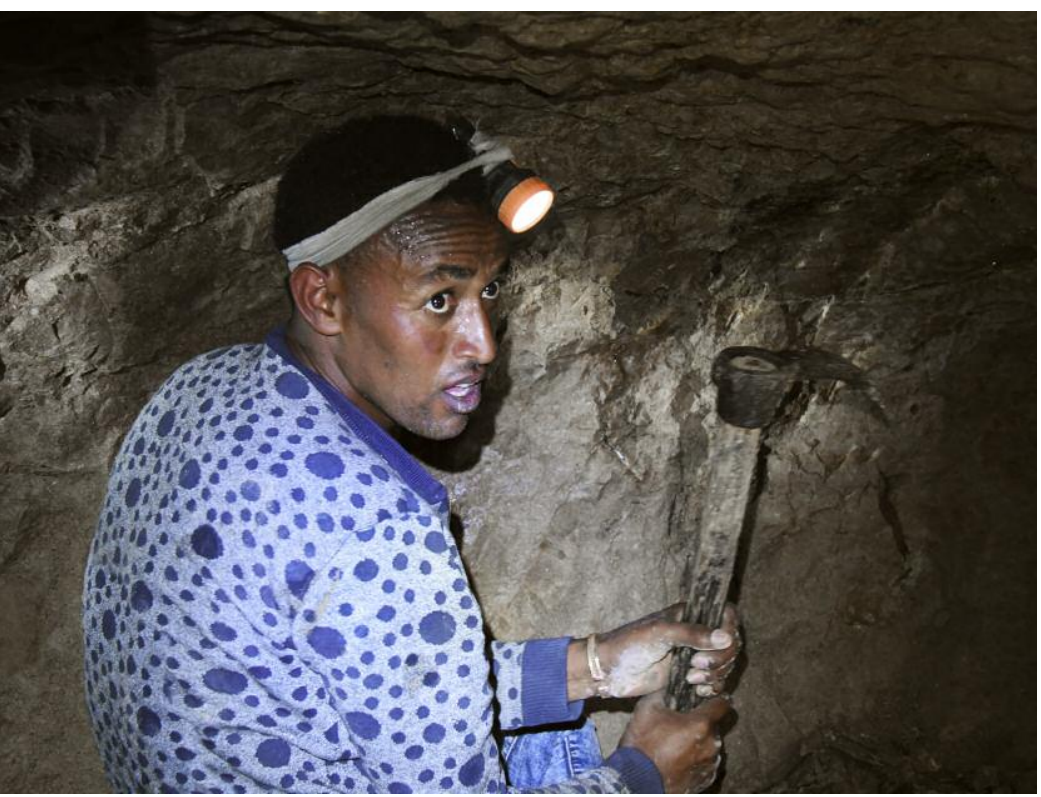

Figure 13. An opal miner works in the tunnel using simple hand tools. Photo by Wim Vertriest.

gen levels are more depleted, which makes the work very difficult. Miners only remove opal-bearing rocks, since the others are not profitable. Once the opalbearing rocks are loosened, miners carry them by hand toward the exit for further processing.

According to a mining association representative, more than 20 tunnels are active in the valley, and each produces $50-100 \mathrm{~kg}$ of opal on a weekly basis.

\section{PROPERTIES OF ETHIOPIAN OPAL}

Ethiopian opal has been mined in various qualities. Bodycolors include white, chocolate brown, reddish

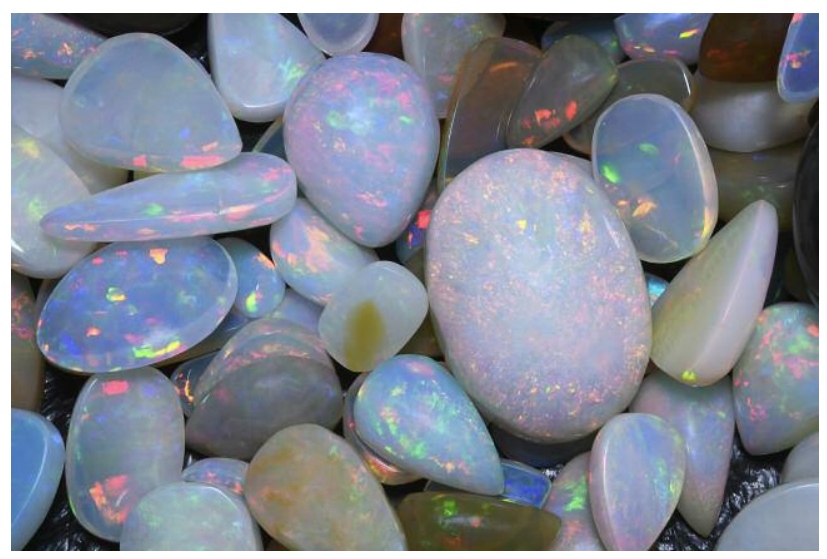

Figure 15. Parcel of mixed Ethiopian opals. Photo by Wim Vertriest.

brown, black, and even colorless (figures 14 and 15). Sizes range from small grains to massive chunks, and pieces over 500 grams are routinely found.

The majority of Ethiopian opal is hydrophane, which means it absorbs water. This may affect the appearance of the stone, causing play-of-color, transparency, or crazing. There are different degrees of porosity, so not every type of Ethiopian opal reacts in the same way. While some of these effects are reversible through dyeing and impregnation, the processes and exact parameters are not yet fully understood. This has led to many controversies about the stability and treatment of Ethiopian opals.

All types of opal-precious or common, stable or requiring treatment-are found together in the same layer and the same tunnels.

Figure 14. Large rough pieces of transparent precious opal (left) and brown precious opal (right). Photos by Wim Vertriest.
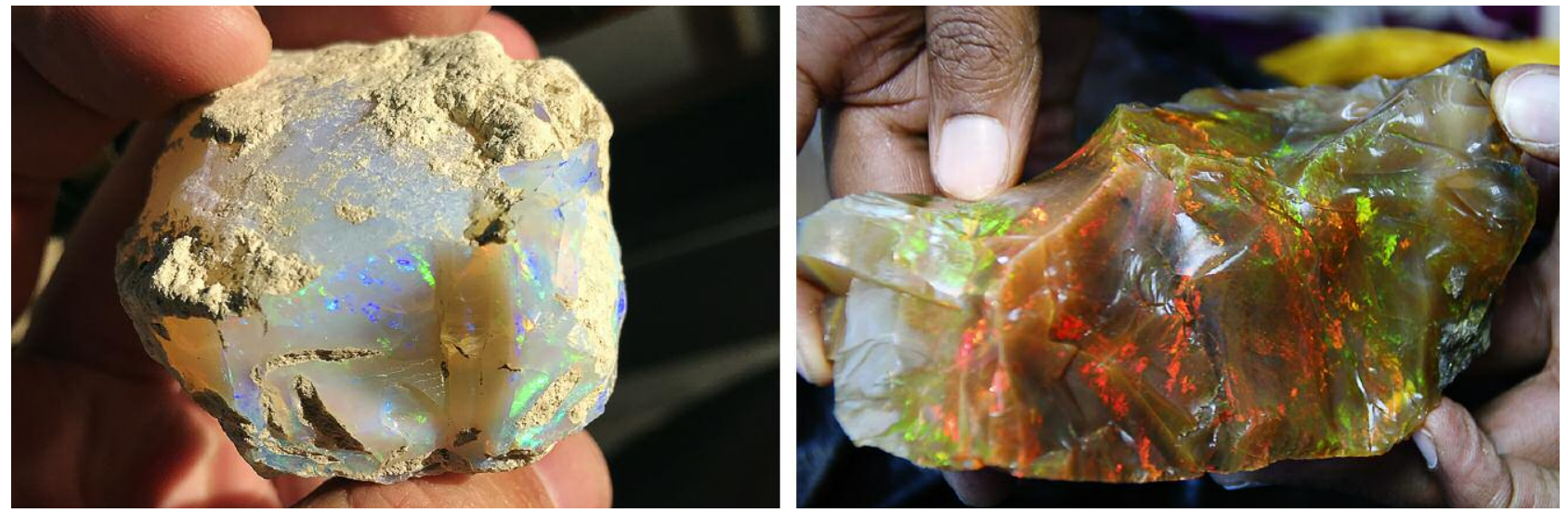


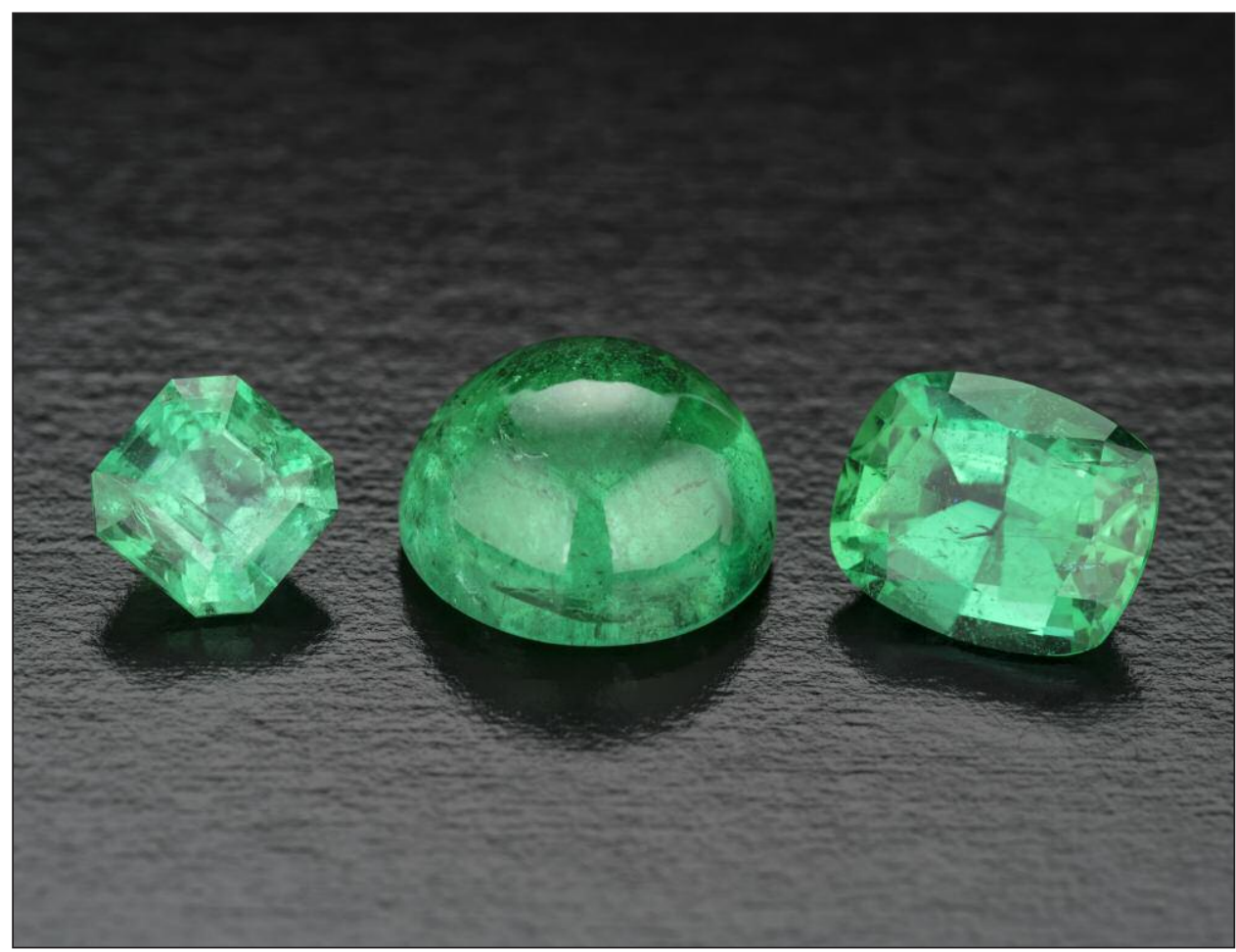

Figure 16. Ethiopian emeralds from the Hallo mine (left to right): a $2.00 \mathrm{ct}$ square emerald cut, a $9.72 \mathrm{ct}$ cabochon, and a 4.12 ct modified cushion cut. Photo by Robert Weldon/GIA, courtesy of Mayer et Watt.

\section{ETHIOPIAN EMERALD}

Background and History. News of Ethiopian emerald first reached the trade in 2011-2012, when a few smaller pieces $(<2 \mathrm{ct}$; see figure 16) reached the market (Cevallos et al., 2012). According to Farooq Hashmi (Intimate Gems, New York), they were mined near Dubuluk. Since the initial discovery, Gemfields acquired an emerald mining license in southern Ethiopia near the town of Web and started developing this in 2017 (Pardieu and Barriere-Doleac, 2018). In late 2016, the first emeralds from the Shakiso area started reaching international markets, with parcels showing up at GIA's labs in Bangkok and Carlsbad, California (Renfro et al., 2017).

Shakiso is a trading town in southern Ethiopia, located on a large highway that links Addis Ababa with northern Kenya. The city is used for trade because access is convenient and some accommodations are available.

The area around Shakiso looks very different from the opal and sapphire mining areas. Because it is closer to the equator and at medium elevation (between 1,600 and 2,000 meters), precipitation is more evenly spread throughout the year and dense vegetation covers the hills. During the trip from Hawassa to Shakiso, we drove for a few hours through the Great African Rift past Lake Hawassa before climbing out of the valley into the green highlands. Cloudy skies and misty conditions provided a setting that was nothing like the arid, sunny conditions near the opal and sapphire mines. Dense forests alternated with grassy bogs in the shallower areas near creeks. This continuous humidity, combined with tropical temperatures and abundant vegetation, increases the weathering rate of outcropping rocks, making it very challenging to study geology in the area.

Secondary deposits where resistant minerals are concentrated are very common, but most of them are gold and coltan minerals, not gemstones. The area has a long tradition of mining, and many deposits of gold and tantalum have been mined artisanally for years. Some very large tantalum mines also operate in the region, as do several smaller cooperatives. In 2014, the Kenticha mine contributed 3\% of the world's supply of tantalum (Yager, 2014).

The mines are located around the small mining village of Kenticha, more than $60 \mathrm{~km}$ from Shakiso, and the drive took over five hours. Recent rainfall had turned the dirt roads into muddy tracks, causing even the most rugged four-wheel-drive trucks to slip and slide all the way from Shakiso to Kenticha.

Trading. Emeralds near Kenticha were discovered in 2016 by local diggers looking for other precious minerals. This triggered a rush of miners, and an artisanal mining community formed in the first months of 
2017. Because the area has been mined extensively for gold and tantalum, many residents have experience in mineral extraction and trading. They quickly set up new professional structures or adapted old ones. Many miners have grouped themselves into cooperatives. This allows them to step away from the unlicensed artisanal arrangement into one that is more regulated, where everyone still has a voice.

The cooperative we visited, Bua Obsa, had been mining gold and tantalum for more than 15 years, but it has grown from 15 members to more than 300 since the emerald discovery. All the members are active in the mining operation, either as support staff or mining personnel. While they had a clearly defined organization with people trained in finance, law, export procedures, and management, they needed to develop the specific skills required to run a colored stone mining and trading operation. The Bua Obsa cooperative quickly realized its shortcomings and partnered with foreign-trained experts. During our visit we met an experienced mining foreman from the Zambian emerald mines and a highly trained geologist with an academic career at the University of Addis Ababa.

This partnership approach allowed Bua Obsa to expand the mine quickly and in a controlled way. Instead of learning the hard way, through trial and error, they partnered with existing knowledge. At the time of our visit, more than seven cooperatives were working in the area, as well as many active smallscale or individual mines. This changed in the second half of 2018, when Bua Obsa became the dominant cooperative in the area. It now represents the lion's share of the miners. Local dealers buy the material near the mines and bring it to Shakiso, the main trading hub for emeralds mined by the small-scale artisanal miners. From there, the material goes to Addis Ababa, where it is presented to international clients. Larger cooperatives such as Bua Obsa have mining and export licenses and are able to export directly to foreign customers/wholesalers.

Because the cooperatives are formed by the local community, there is very strong local support for the emerald mining. During the artisanal rush, miners flocked to the small village of Kenticha, expanding it greatly. After the rush, many of them left to try their luck elsewhere. Kenticha is now inhabited by about 1,000 people, mostly natives of the surrounding area.

Emeralds from God's Hand. Large companies have been mining and exploring the Kenticha area for gold and tantalum since the 1980s, often neglecting local communities. Now that the cooperatives have discovered this new emerald resource in one of the most extensively explored areas of Ethiopia, the situation is much different. The Bua Obsa cooperative considers this a gift from God. The wealth generated by these emeralds will directly contribute to the local communities. Within one year, the cooperative had already built roads, medical outposts, and churches with the profits from emerald mining.

Geology. The local geology is very well known due to the exploration for gold and tantalum. The presence of tantalum in particular provides interesting insights into the emeralds' geology. Tantalum mineralization is related to pegmatites, which are also the source for beryl. The pegmatites are related to granite intrusions. These molten rocks intruded right after the formation of the East African orogenic belt. The host rock consists of numerous mafic units, ranging from mafic schists to ultramafic serpentinite bodies. These can have magmatic origins (ophiolites) or a metasedimentary origin (pelitic schists, graphite schists, and marbles) (Küster et al., 2009; Tadesse, 2001). These host rocks are part of the Mozambique Belt, which is related to many other East African gem deposits.

When the pegmatites intruded, a reaction zone formed between the intrusion and the host rock. This zone consists predominantly of dark mica (biotite) but also hosts minerals that are a blend of both rock types. The best example is emerald, which is a beryl (pegmatite-influenced) with chromium trace elements (influenced by the host rock).

We could clearly see the dark mafic host rocks and one white pegmatite intrusion. The pegmatite ranges in thickness from five meters to a couple of centimeters. According to the mine geologist, two types of emeralds are found. One is found in the pegmatite and is much lighter and of lower quality. This is due to the abundance of silica and virtual absence of chromium in the pegmatite. The other type is found in the reaction zone, where chromium is abundant and there is a lot of space to grow in between the mica crystals. He also told us that there are multiple pegmatite intrusions close to each other and that all of them are emerald bearing. A couple of meters south of the mining pit, a pegmatite intrusion reaches the surface.

Mining. According to the local people, early emerald mining was strictly artisanal. Initial discoveries were made where the pegmatites reached the surface, but the mining quickly moved to deeper ground. Small crews would sink shafts vertically until they reached 


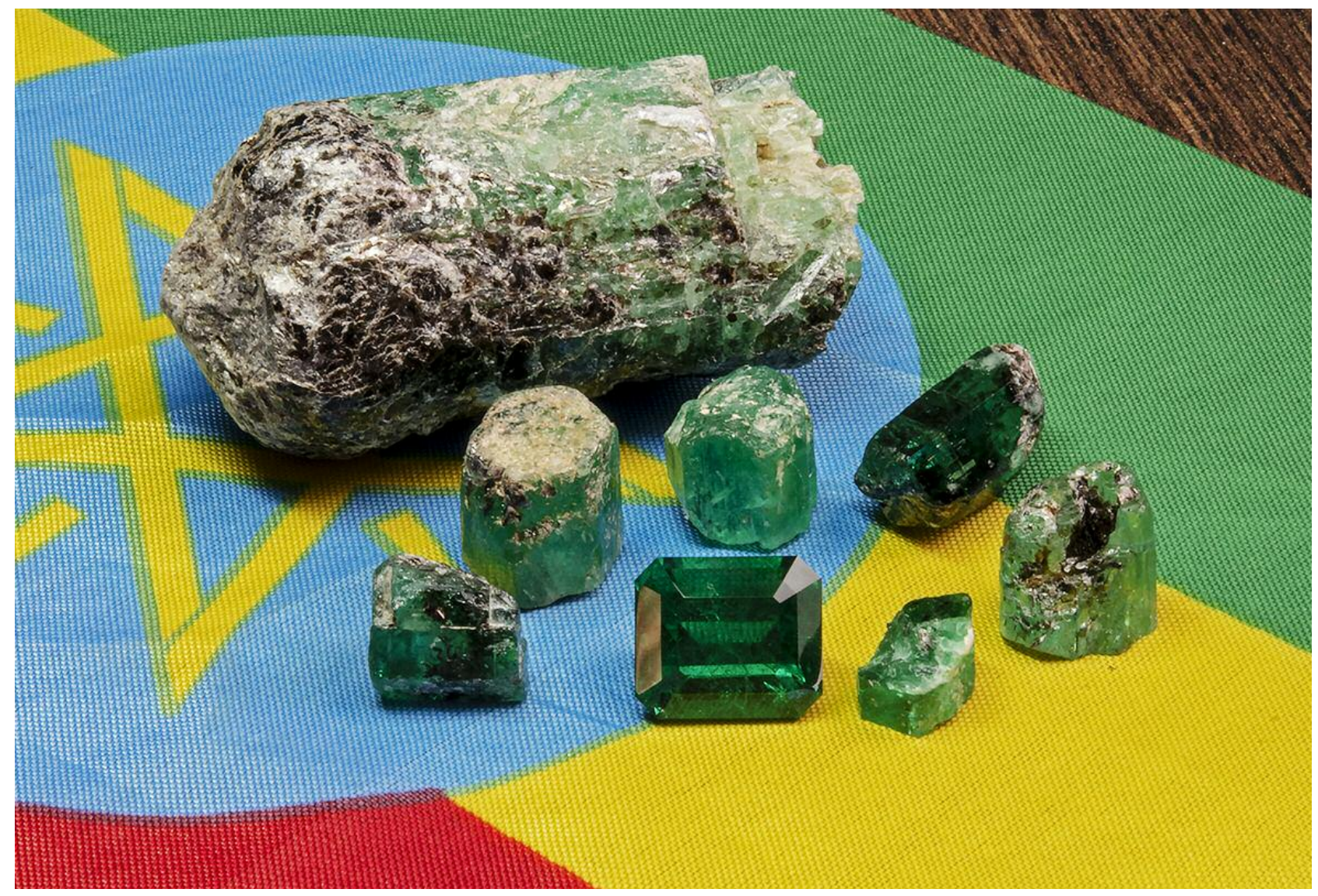

Figure 17. Ethiopian emeralds, in the rough and faceted ( $8.03 \mathrm{ct}$, no fracture filling). The rough stones are from the GIA reference collection, and the faceted emerald is courtesy of Jeffery Bergman (Primagem). Photo by Wim Vertriest.

the emerald-bearing rocks. This was all done using hand tools, sometimes digging 20 meters deep (Schollenbruch et al., 2017). More than 10,000 miners were active in the small area at its peak in spring 2017.

With the formation of the cooperatives, mining became more professional. The Bua Obsa cooperative is currently working a large open-pit mine, exposing all the rocks and selectively extracting emeralds. The pit was about 25 meters deep and 50 by 50 meters long at the time of our visit. It is located on top of the hill where the emeralds were originally discovered. Overburden is carefully stripped away, and safe routes are created to descend into the mine. Wall stability is also monitored. This results in periods where the mine is not productive, but these steps are required to develop the mine and ensure safety. Bua Obsa uses large equipment, including bulldozers and excavators; emerald picking, sorting, and washing is still done manually. This larger-scale mining requires coordination and experience, which is why they have hired a foreman who worked in the Zambian emerald mines for more than 20 years.

\section{PROPERTIES OF ETHIOPIAN EMERALD}

Visual Characteristics. The Ethiopian emeralds have a wide range of qualities and sizes. Material with lighter colors is usually cleaner, but clean deep green crystals have been found (figure 17). While most of the emeralds are fairly small, large crystals have been recovered, some weighing more than 600 grams. Crystals are often (sub-) euhedral with clean terminations. The roots are commonly more included. Rough emeralds are coated in mica, which is sometimes speckled throughout the entire stone. Color zoning is regularly seen. Some stones have a cloudy whitish appearance, probably due to an abundance of fine quartz inclusions. As with emeralds from all localities, some material requires enhancement by fracture filling. 

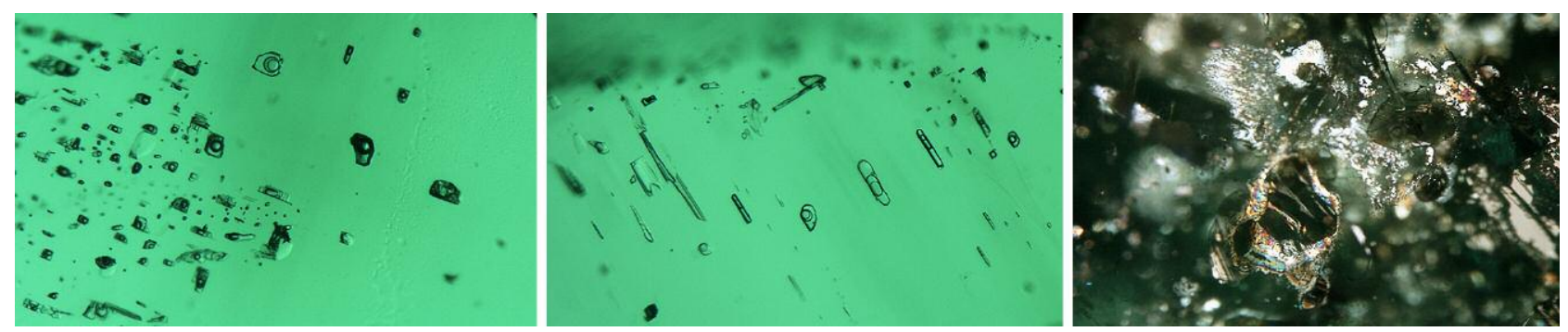

Figure 18. Left: Blocky, irregular two- and three-phase inclusions. Diffused illumination; field of view $0.8 \mathrm{~mm}$. Center: Elongated three-phase inclusions with separated gas phases. Diffused illumination; field of view $0.7 \mathrm{~mm}$. Right: Brownish phlogopite mica crystals surrounded by planes of thin films. Fiber-optic illumination; field of view $2.0 \mathrm{~mm}$. Photomicrographs by Ungkhana Atikarnsakul.

Standard Gemological Properties. The Ethiopian emeralds had an average density of $2.72 \mathrm{~g} / \mathrm{cm}^{3}$, ranging from 2.68 to $2.76 \mathrm{~g} / \mathrm{cm}^{3}$. Refractive index ranged from 1.580 to 1.590 , with an average birefringence of 0.008 . None of our samples showed any reaction under longwave or short-wave UV light or in the Chelsea filter.

Inclusions. The inclusions in Ethiopian emerald can be divided into three groups. The first consists of variously shaped fluid inclusions that are often blocky (figure 18, left). Depending on the viewing angle, they appear more irregular or elongated (figure 18, center). It is estimated that the gas phase takes up $40-50 \%$ of the crystal's volume at room temperature. Some inclusions exhibit two separate gas phases at room temperature but quickly homogenize when they are held over the well light in the microscope. This indicates a large $\mathrm{CO}_{2}$ component in the inclusion. In some elongated two-phase inclusions, the tip is tapered, resembling a nailhead spicule inclusion. Under high magnification, small crystals can be seen within the fluid inclusions. Fingerprints with more rounded, smaller secondary fluid inclusions are very common.

Growth patterns such as color zoning, hexagonal growth zones, or even roiled growth features are frequently observed. New generations of emerald form- ing are often associated with these growth zones.

Common crystal inclusions in the emerald are brownish mica identified by Raman spectroscopy as biotite and phlogopite, which form in various sizes and shapes. A phlogopite mica plate was often found together with a granular flake of iridescent thin films (figure 18 right). Colorless quartz crystal can also be observed in Ethiopian emerald. Rarer inclusions, identified as calcite, talc, bertrandite, magnetite spinel, and chlorite, are found in some samples.

Spectroscopy. UV-Vis-NIR spectroscopy showed two broad bands related to $\mathrm{Cr}^{3+}$, at around 430 and 600 $\mathrm{nm}$ for the ordinary ray (o-ray) and 420 and $630 \mathrm{~nm}$ for the extraordinary ray (e-ray). Fe causes the narrow band around $372 \mathrm{~nm}$ related to $\mathrm{Fe}^{3+}$ and the strong broad band around $810 \mathrm{~nm}$ related to $\mathrm{Fe}^{2+}$, which is most clearly expressed in the o-ray spectrum.

No spectroscopic features indicate that $\mathrm{V}^{3+}$ contributes significantly to the color of these stones.

Trace-Element Chemistry. We selected 25 samples for trace-element analysis using LA-ICP-MS (table 2) and analyzed three to eight spots per sample, resulting in 134 total measurements. Ethiopian emeralds are characterized by a relatively high content of

TABLE 2. LA-ICP-MS trace-element concentrations in Ethiopian emeralds (ppmw).

\begin{tabular}{|c|c|c|c|c|c|c|c|c|c|c|c|c|c|}
\hline & ${ }^{7} \mathrm{Li}$ & ${ }^{23} \mathrm{Na}$ & ${ }^{24} \mathrm{Mg}$ & ${ }^{39} \mathrm{~K}$ & ${ }^{45} \mathrm{Sc}$ & ${ }^{51} \mathrm{~V}$ & ${ }^{53} \mathrm{Cr}$ & ${ }^{57} \mathrm{Fe}$ & ${ }^{60} \mathrm{Ni}$ & ${ }^{66} \mathrm{Zn}$ & ${ }^{69} \mathrm{Ga}$ & ${ }^{85} \mathrm{Rb}$ & ${ }^{133} \mathrm{Cs}$ \\
\hline Min. & 183 & 7830 & 9140 & 99 & 31 & 75 & 95 & 1970 & 5 & 21 & 14 & 15 & 151 \\
\hline Max. & 446 & 16700 & 16800 & 889 & 111 & 129 & 3760 & 5320 & 21 & 146 & 25 & 166 & 544 \\
\hline Avg. & 309 & 11175 & 12690 & 310 & 74 & 103 & 1441 & 3890 & 11 & 53 & 20 & 57 & 355 \\
\hline Stand. dev. & 59 & 1760 & 1215 & 98 & 19 & 10 & 1045 & 463 & 4 & 15 & 2 & 17 & 79 \\
\hline Det. limit & 0.42 & 21.54 & 0.59 & 11.09 & 0.87 & 0.28 & 4.50 & 21.12 & 0.77 & 1.17 & 0.21 & 0.15 & 0.05 \\
\hline
\end{tabular}




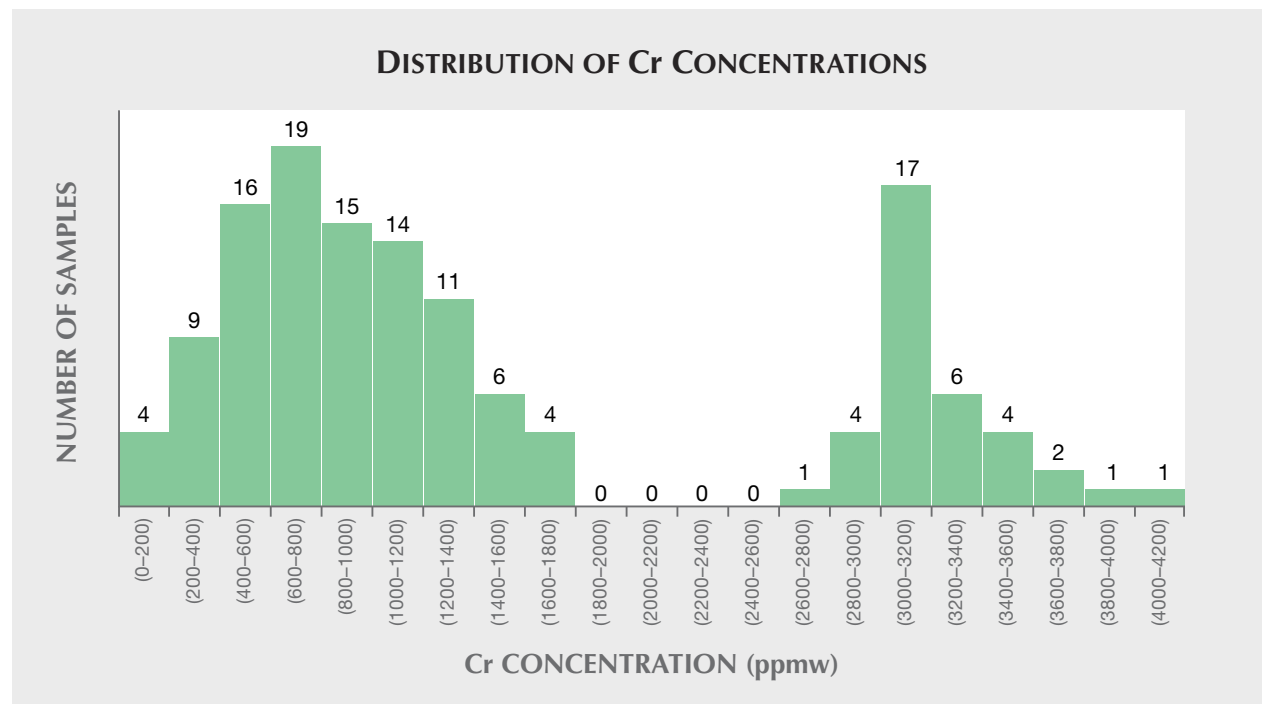

Figure 19. The distribution of Cr concentrations (ppmw) clearly shows that there are two types of Ethiopian emerald: one that is Cr-rich and one with lower Cr concentrations. This is probably closely related to their formation mechanism.

alkaline ions ( $\mathrm{Li}, \mathrm{Na}, \mathrm{K}, \mathrm{Rb}$, and $\mathrm{Cs})$. Vanadium is found in the emerald but does not influence the color. It is noteworthy that $\mathrm{Cr}$ and Fe values show a large range and the Cr values have a very large standard deviation. Cr values ranged from 95 ppmw to more than 3700 ppmw. Examining this data more closely, we see two groups of emeralds with different Cr concentrations, as shown in figure 19, that are under 1800 ppmw and over 2500 ppmw. These groups seem to be defined only by their $\mathrm{Cr}$ values and not by other chemical concentrations of trivalent ions such as Fe and V. This difference can be related to initial geological observations. According to the mine's geologist, emeralds are found in two different rock types: in the pegmatite and in the reaction zone. This geological model would explain the difference in color and in $\mathrm{Cr}$ content, where the emeralds from the reaction zone are richer in chromium and have a deeper color than the beryl formed in the pegmatite.

Since emerald inclusions are very similar for most pegmatite-related emerald deposits, trace-element analysis is a critical technique for origin determination. Emeralds from Zambia, Russia, Brazil, Pakistan, and Madagascar can be separated from Ethiopian material based on chemical composition, although some overlap can occur.

\section{CONCLUSIONS}

Ethiopia has an incredibly rich history spanning several millennia, but gemstones were not a part of this history until a decade ago. Opal was the first Ethiopian gemstone that rose to fame, emerging from the northern province of Wollo in large volume and various qualities. This colorful gemstone has faced scrutiny over its stability. Our visit to the mining area granted us insight into the grueling work to retrieve opal from the hard rock tunnels in the highlands.

The Ethiopian sapphire fields of Tigray Province, also in the northern part of the country, have only recently been discovered and are being worked in very rudimentary fashion. The secondary deposits supply dark to light blue sapphires that often require heat treatment. Few qualify as high-end material, but they are finding a strong market as commercial grade. The area has no sapphire mining history, but the local miners are learning quickly. The future will tell whether more sapphire-bearing areas will be discovered and mining processes can be improved. Both are equally important to sustain Ethiopia as a sapphire-producing region.

At the moment, Ethiopia's most sought-after gemstones are the emeralds from the southern part of the country. Since their discovery in the Shakiso area in late 2016, the growth of the deposit has been remarkable. The mining quickly shifted from a chaotic artisanal rush to a well-organized larger-scale operation aiming to cover the entire mine-to-market line. The emeralds can reach impressive sizes, and high-quality material has gone on the market. Based on their inclusions, these could be confused with emeralds from other pegmatite-related sources such as Zambia, Brazil, or Russia, but trace-element chemistry can often separate Ethiopian origin.

Since 2017, Ethiopia has proven to be one of the most interesting gem-producing countries, with large reserves of sapphire and emerald coming onto the market. During our expedition we could see that the 
local gemstone industry was still in its infancy but growing at breathtaking speed. Ethiopian dealers, exporters, and governments are gathering knowledge about new deposits, other gem varieties, and gemstone manufacturing to make the most of these immense gemstone resources.

\section{ABOUT THE AUTHORS}

Mr. Vertriest is supervisor of field gemology, Ms. Wongrawang is a staff gemologist for colored stones, and Ms. Atikarnsakul is a colored stone analyst, at GIA in Bangkok. Mr. Girma is an analytics technician for colored stones at GIA in New York. Mr. Schumacher is a photo and video producer for Gems \& Gemology at GIA in Carlsbad, California.

\section{ACKNOWLEDGMENTS}

This expedition was made possible through the support of the Ethiopian Ministry of Mines, Petroleum and Natural Gas. Specifically, Mr. Teweldbrahn Abay, Mr. Getachew Addis, and Mr. Biniyam Bekele helped with administration and on-ground support. This expedition was successful only because of the great team that traveled to the mines with us: Andy Lucas (former GIA field gemologist) and external consultants Steve Curtis and Alessandro Martello. We are thankful to the Bua Obsa cooperative for hosting us at their mine site, especially to Mr. Adisse Mekonnen (chief geologist) and Mr. Wodessa Yachisi Bululta (association president). The data in this article was collected by GIA's colored stone teams and in particular Charuwan Khowpong, Vararut Weeramonkhonlert, Sasithorn Engniwat, and Suwasan Wongchacree. Thank you to Pedro Padua and Betsy Winans, both of GIA, for assistance with video editing.

Of course, this article would not have been possible without the support and effort of the people and gem mining communities throughout Ethiopia.

\section{REFERENCES}

Cevallos P., Simmons W.B., Falster A.U. (2012) Gem News International: Emerald from Ethiopia. $G \uplus G$, Vol. 48, No. 3, pp. 219 221.

Ham A., Carillet J.-B. (2017) Lonely Planet Ethiopia « Dibouti. Lonely Planet Global Limited.

Kiefert L., Hardy P., Sintayehu T., Abate B., Woldetinsae G. (2014) Gem News International: New deposit of black opal from Ethiopia. Gせ G, Vol. 50, No. 4, pp. 303-305.

Koivula J.I., Fritsch E., Eds. (1994) Gem News: Opal from Ethiopia. Ge) G, Vol. 30, No. 1, pp. 52-53.

Küster D., Romer R.L., Tolessa D., Zerihun D., Bheemalingeswara K., Melcher F., Oberthür T. (2009) The Kenticha rare-element pegmatite, Ethiopia: Internal differentiation, U-Pb age and $\mathrm{Ta}$ mineralization. Mineralium Deposita, Vol. 44, No. 7, pp. 723750, http://dx.doi.org/10.1007/s00126-009-0240-8

Pardieu V., Barriere-Doleac D. (2018) Ethiopia, land of origins part I: Emeralds from southern Ethiopia. https://www.youtube.com/ watch? $\mathrm{v}=9 \mathrm{eKiYe} 1 \mathrm{LRbc}$

Renfro N., Sun Z., Nemeth M., Vertriest W., Raynaud V., Weeramonkhonlert V. (2017) Gem News International: A new discovery of emeralds from Ethiopia. $G \uplus G$, Vol. 53, No. 1, pp. 114-116.

Rondeau B., Cenki-Tok B., Fritsch E., Mazzero F., Gauthier J.-P., Bodeur Y., Bekele E., Gaillou E., Ayalew D. (2012) Geochemical and petrological characterization of gem opals from Wegel Tena, Wollo, Ethiopia: Opal formation in an Oligocene soil. Geochemistry: Exploration, Environment, Analysis, Vol. 12, No. 2, pp. 93-104, http://dx.doi.org/10.1144/1467-7873/10MINDEP-058.

Rondeau B., Fritsch E., Gauthier J.-P., Mazzero F., Bekele E. (2009) A new source of play-of-color opal at Wegel Tena, Welo Province, Ethiopia. 31st International Gemmological Congress-Abstracts, Arusha, Tanzania, pp. 43-44.

Rondeau B., Fritsch E., Mazzero F., Gauthier J.-P., Cenki-Tok B., Bekele E., Gaillou, E. (2010) Play-of-color opal from Wegel Tena, Wollo Province, Ethiopia. GÆG, Vol. 46, No. 2, pp. 90-105, http://dx.doi.org/10.5741/GEMS.46.2.90

Schollenbruch K., Link K., Sintayehu T. (2017) Gem quality emeralds from southern Ethiopia. InColor, Vol. 35, pp. 48-54.

Tadesse S. (2001) Geochemistry of the pegmatitic rocks and minerals in the Kenticha Belt, southern Ethiopia: Implication to geological setting. Gondwana Research, Vol. 4, No. 1, pp. 97104, http://dx.doi.org/10.1016/S1342-937X(05)70658-4

Vertriest W., Weeramonkhonlert V., Raynaud V., Bruce-Lockhart S. (2017) Gem News International: Sapphires from northern Ethiopia. GÆG, Vol. 53, No. 2, pp. 247-248.

Yager T. (2014) The mineral industry of Ethiopia. In 2014 Minerals Yearbook, U.S. Geological Survey, Reston, Virginia.

\section{For More on the Ethiopian Gem Industry}

View the diverse Ethiopian landscapes and deposits, watch interviews with gem miners and dealers, and get insights from field gemologists. Visit www.gia.edu/gems gemology/ spring 2019 land origins gemological expedition ethiopia
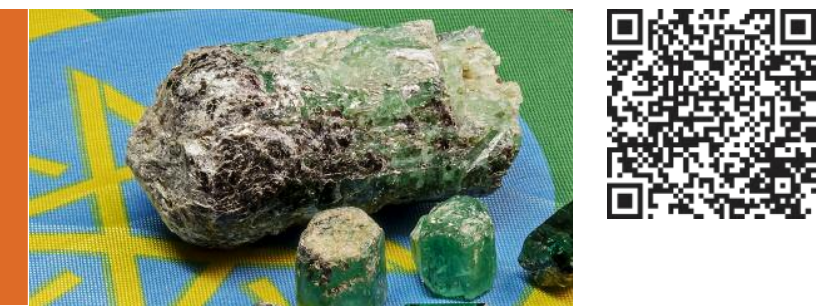